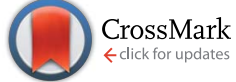

Cite this: RSC Adv., 2017, 7, 14323

Received 19th November 2016 Accepted 23rd February 2017

DOI: $10.1039 / c 6 r a 27026 c$

rsc.li/rsc-advances

\section{Alkaloids and polyketides from the South China Sea sponge Agelas aff. nemoechinata $\dagger$}

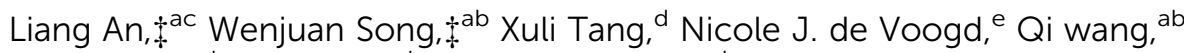 \\ Meijun $\mathrm{Chu}^{\text {ab }}$ Pinglin Li*ab and Guoqiang Li*ab
}

A chemical investigation of the South China Sea sponge Agelas aff. nemoechinata yielded three pairs of new enantiotopic pyrrole alkaloids nemoechines A-C (1-3), one new diterpene-adenine alkaloid nemoechine D (8), and one new polyketide nemoechioxide A (10), together with nine known analogues $(4-7,9,11-14)$. Compounds 1-3 were initially obtained as racemates and were further separated by chiral HPLC chromatography to afford the three pairs of enantiomers. Their structures including absolute configurations of compounds 1-3 were elucidated on the basis of comprehensive spectroscopic analysis and quantum chemical calculation. Nemoechine A (1), possessing an unusual cyclopentane-fused imidazole ring system, represents the first monomeric precursor of nagelamide J. Compounds 8 and 9 showed cytotoxicity against HL-60 cell lines with $I_{50}$ values of 9.9 and $0.9 \mu \mathrm{M}$, respectively, and compound 9 was also cytotoxic against HeLa cell lines with $I_{50}$ value of $8.9 \mu \mathrm{M}$.

\section{Introduction}

Marine sponges of the genus Agelas (family Agelasidae), with recorded forty-six species, ${ }^{1}$ are a rich source of pyrrole alkaloids and diterpenoid alkaloids. ${ }^{2}$ These metabolites exhibit a broad bioactivity such as antileukemic, ${ }^{3}$ antibacterial, ${ }^{4}$ antimalarial, ${ }^{5}$ and antifouling activities. ${ }^{6}$ It should be noticed that previous investigations on the genus Agelas, since the isolation of oroidin from $A$. oroides in $1971,{ }^{7}$ mainly focus on those species collected from Okinawa, the Bahamas, and Caribbean islands, apart from only one report on the South China Sea sponge A. mauritiana by Hou-Wen Lin's group in $2012,{ }^{8}$ which implied a potential chemo-diversity of Agelas sponges in this area.

As part of our searching for new bioactive natural products from Xisha islands (Paracel islands) sponges, ${ }^{9}$ the systematic chemical work on a Agelas aff. nemoechinata species has yielded diverse natural compounds including pyrrole alkaloids and rare $\mathrm{N}$-methyladenine-containing diterpenes. ${ }^{\mathbf{1 0}}$ Herein, we reported

${ }^{a}$ Key Laboratory of Marine Drugs, Chinese Ministry of Education, School of Medicine and Pharmacy, Ocean University of China, Qingdao 266003, People's Republic of China.E-mail: lipinglin@ouc.edu.cn; liguoqiang@ouc.edu.cn

${ }^{b}$ Laboratory for Marine Drugs and Bioproducts of Qingdao National Laboratory for Marine Science and Technology, China

'Qingdao Huanghai Pharmaceutical Co., Ltd, Qingdao 266101, People's Republic of China

${ }^{d}$ College of Chemistry and Chemical Engineering, Ocean University of China, Qingdao 266100, People's Republic of China

${ }^{e}$ National Museum of Natural History, 2300 RA Leiden, The Netherlands

$\dagger$ Electronic supplementary information (ESI) available. See DOI: 10.1039/c6ra27026c

\$ L. An and W.-J Song contributed equally to this paper.

the isolation, structural elucidation and the cytotoxic activity of fourteen metabolites structurally belonging to three structure families of pyrrole alkaloids (1-7), diterpene-adenine alkaloids (8 and 9), and polyketides (10-14), including three new pyrrole alkaloids nemoechines A-C (1-3), one new diterpene-adenine

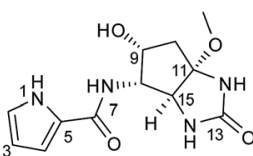

(+) $-18 R, 9 S, 11 R, 15 R$

$(-)-18 S, 9 R, 11 S, 15 S$<smiles>COC(=O)CNC(=O)c1ccc[nH]1</smiles>

4

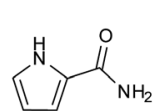

7<smiles></smiles>

$(+)-29 R$

$(-)-29 S$<smiles>NCCNC(=O)c1ccc[nH]1</smiles>

5

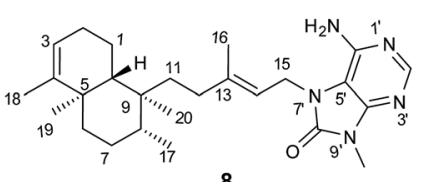

8

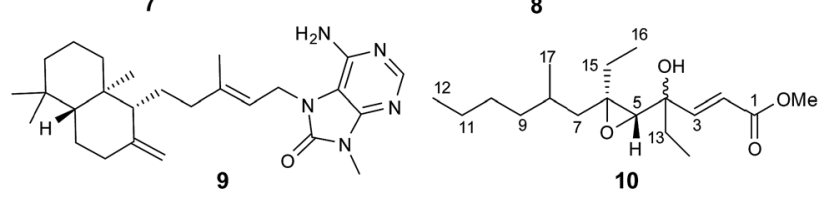

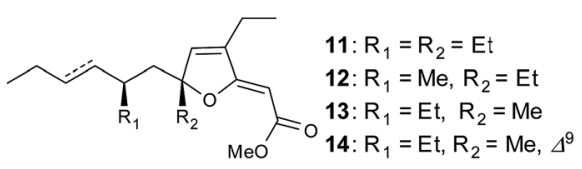

Fig. 1 Structures of compounds 1-14. 
alkaloid nemoechine D (8) and one new polyketide nemoechioxide A (10) (Fig. 1). Compounds 1-3 were initially obtained in the form of racemates and were further separated by chiral HPLC chromatography to afford the three pairs of enantiomers. And compound $\mathbf{1}$ has an unusual skeleton distinguished by a bicyclic cyclopentene-fused imidazole moiety. Compounds $\mathbf{8}$ and $\mathbf{9}$ showed significant cytotoxicity against selected tumor cell lines.

\section{Result and discussion}

Nemoechine A (1) was obtained as a colorless amorphous solid. The molecular formula of 1 was deduced to be $\mathrm{C}_{12} \mathrm{H}_{16} \mathrm{~N}_{4} \mathrm{O}_{4}$ by its HRESIMS data, requiring seven degrees of unsaturation. The IR absorption bands at 3266, 1684, and $1649 \mathrm{~cm}^{-1}$, together with UV absorption at $\lambda_{\max } 267 \mathrm{~nm}$ indicated the presence of a pyrrole amide moiety, ${ }^{11}$ which was consistent with the typical ${ }^{1} \mathrm{H}$ and ${ }^{13} \mathrm{C}$ NMR (DEPT) signals (Table 1$)$ at $\delta_{\mathrm{H}} 11.51(1 \mathrm{H}$, br s, NH-1), $6.86(2 \mathrm{H}$, br s, H-2 and $\mathrm{H}-4)$, and $6.09(1 \mathrm{H}, \mathrm{br} \mathrm{s}, \mathrm{H}-3)$, and $\delta_{\mathrm{C}} 160.2(\mathrm{~d}, \mathrm{C}-6), 121.3$ (d, C-2), 126.1 (d, C-5), 110.8 (d, C-4), and 108.5 (d, C-3). ${ }^{11}$ The consecutive ${ }^{1} \mathrm{H}^{-1} \mathrm{H}$ COSY correlations from $\mathrm{H}-1$ to $\mathrm{H}-5$, and $\mathrm{HMBC}$ correlation of $\mathrm{H}-7\left(\delta_{\mathrm{H}} 7.72, \mathrm{~d}, J=6.95 \mathrm{~Hz}\right)$ with C-6 further improved the aforementioned assignment to be a pyrrole-5-formylamine core (Fig. 2). Considering the other amide carbonyl group signal at $\delta_{\mathrm{C}} 160.7$ (q, C-13) in ${ }^{13} \mathrm{C}$ NMR spectrum, compound 1 was deduced to have an additional bicyclic moiety for the unsaturation requirement. Detailed analyses of COSY and HMQC spectra disclosed a spin-spin coupling system of NH-14/CH-15/CH-8/(NH7) $\mathrm{CH}-9 / \mathrm{CH}_{2}-10$. The HMBC correlations from $\mathrm{H}-14\left(\delta_{\mathrm{H}} 6.93, \mathrm{~s}\right)$ to C-13 and C-15 $\left(\delta_{\mathrm{C}}\right.$ 62.9), from $\mathrm{H}-12\left(\delta_{\mathrm{H}} 7.32, \mathrm{~s}\right)$ to $\mathrm{C}-11\left(\delta_{\mathrm{C}} 94.7\right)$ and $\mathrm{C}-13$, and from $\mathrm{H}_{2}-10\left(\delta_{\mathrm{H}} 2.16, \mathrm{dd}, J=13.62,5.10 \mathrm{~Hz}\right)$ to $\mathrm{C}-11$ and $\mathrm{C}-15$ suggested the bicyclic moiety to be a cyclopentane-fused 2-oxoimidazolidin through C-11 and C-15. The methoxyl group at C-11 was evident from the HMBC correlation from OMe $\left(\delta_{\mathrm{H}} 3.07, \mathrm{~s}\right)$ to $\mathrm{C}-11$, and the hydroxyl group at C-9 was deduced from COSY

Table 1 NMR data (DMSO- $d_{6}$ ) of compound $1^{a}$

\begin{tabular}{llll}
\hline Position & $\delta_{\mathrm{C}}$ & $\delta_{\mathrm{H}}(J$ in Hz $)$ & HMBC $(\mathrm{H} \rightarrow \mathrm{C})$ \\
\hline 1 & & 11.51, br s & \\
2 & 121.3 & $6.86, \mathrm{br} \mathrm{s}$ & $3,4,5$ \\
3 & 108.5 & $6.09, \mathrm{br} \mathrm{s}$ & $2,4,5$ \\
4 & 110.8 & $6.86, \mathrm{br} \mathrm{s}$ & $2,3,5$ \\
5 & 126.1 & & \\
6 & 160.2 & & 6,8 \\
7 & & $7.72, \mathrm{~d}(6.95)$ & $6,9,10,11,15$ \\
8 & 60.8 & $3.88, \mathrm{dd}(11.36,5.62)$ & 10,15 \\
9 & 69.3 & $4.06, \mathrm{dd}(9.94,5.04)$ & $8,11,15$ \\
10 & 44.2 & $2.16, \mathrm{dd}(13.62,5.10)$ & $8,11,15$ \\
& & $2.09, \mathrm{dd}(13.62,5.10)$ & $11,13,15$ \\
11 & 94.7 & & \\
12 & & $7.32, \mathrm{~s}$ & $11,13,15$ \\
13 & 160.7 & & 11 \\
14 & & $6.93, \mathrm{~s}$ &
\end{tabular}

${ }^{a}$ Recorded at $500 \mathrm{MHz}$ for ${ }^{1} \mathrm{H}$ and $125 \mathrm{MHz}$ for ${ }^{13} \mathrm{C}$ NMR.
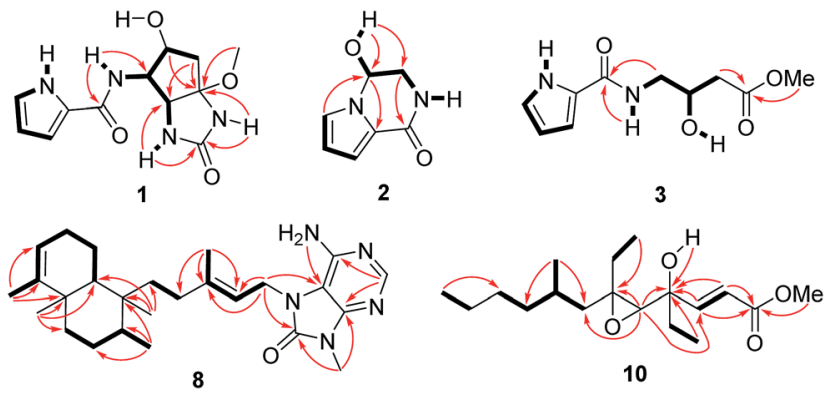

Fig. 2 Key $\operatorname{COSY}(-)$ and $\mathrm{HMBC}(\rightarrow)$ correlations of $1-3,8$ and 10.

correlations of H-9/H-8 ( $\left.\mathrm{H}_{2}-10\right)$ (Fig. 1). Thus, the gross structure of nemoechine A (1) was assigned as depicted.

The relative configurations of the chiral cyclopantane-fused imidazole moiety in $\mathbf{1}$ were deduced from NOE differential spectra. Irradiations of $\mathrm{H}-\mathrm{OMe}$ and $\mathrm{H}-15$ generated respective enhancement of $\mathrm{H}-15$ and $\mathrm{H}-7$, and irritation of $\mathrm{H}-8$ generated enhancement of H-14 and H-9 (Fig. 3 and SS9 in ESI $\dagger$ ), indicating that the bicyclic moiety was cis-fused, and H-8 and H-9 were on the same side of cyclopentane ring, while $\mathrm{OH}-9$, OMe11 and $\mathrm{H}-15$ were on the opposite side. Therefore, $8 S^{*}, 9 R^{*}, 11 S^{*}, 15 S^{*}$ configuration was assigned to 1 , which was identical to that of the partial structure of nagelamide $\mathrm{J}$ from Agelas sp. ${ }^{12}$ However, compound 1 was optically inactive, indicating 1 to be a racemate. The chiral HPLC separation of 1 yielded optical pure compounds (+)-1 and (-)-1, showing opposite optical rotation (OR) values of respective +30.3 and -32.4 , as well as mirror-like cotton effects curves (CEs) (Fig. 4).

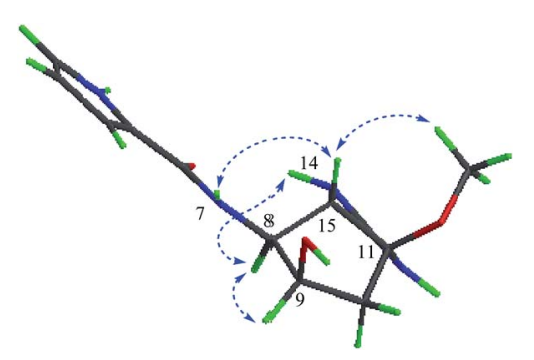

Fig. 3 Key NOSEY correlations of 1.

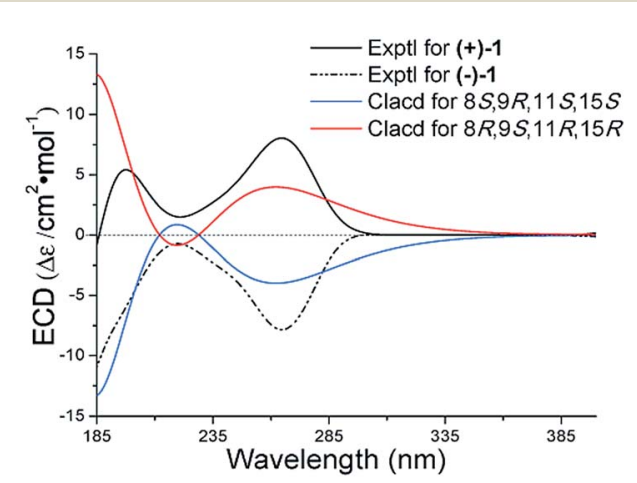

Fig. 4 Experimental $C D$ spectrum of nemoechine $A$ (1) overlaid with calculated spectra (redshifted by $15 \mathrm{~nm}$ ) for the candidate stereostructures. 
TDDFT/ECD calculations at RB3LYP/DGDZVP level indicated that the calculated ECD for $8 R, 9 S, 11 R, 15 R$ configuration matched well with the experimental ECD spectrum of (+)-1 showing a main positive $\mathrm{CE}$ at $264.5 \mathrm{~nm}$, which was opposite to the experimental ECD spectrum of (-)-1 and calculated ECD for $8 S, 9 R, 11 S, 15 S$ configuration (Fig. 3). Accordingly, the absolute configurations of $(+)-\mathbf{1}$ and $(-)-\mathbf{1}$ were determined as $8 R, 9 S, 11 R, 15 R$ and $8 S, 9 R, 11 S, 15 S$ respectively.

Nemoechine B (2), a colorless oil, had molecular formula of $\mathrm{C}_{7} \mathrm{H}_{8} \mathrm{O}_{2} \mathrm{~N}_{2}$ as deduced from HRESIMS and ${ }^{13} \mathrm{C}$ NMR data (Table 2). Its $1 \mathrm{D}$ NMR data suggested 2 as debromo-analogue of longamide isolated from Agelas longissima, ${ }^{13}$ which was confirmed by COSY correlations of $\mathrm{H}-2 / \mathrm{H}-3 / \mathrm{H}-4$ and $\mathrm{H}-7 / \mathrm{H}_{2}-8 /$ $\mathrm{H}-9 / \mathrm{H}-\mathrm{OH}$, together with $\mathrm{HMBC}$ correlations from $\mathrm{H}-2$ to $\mathrm{C}-9$, from $\mathrm{H}-9$ to $\mathrm{C}-5$, from $\mathrm{H}_{2}-8$ to $\mathrm{C}-6$, and from $\mathrm{H}-\mathrm{OH}$ to $\mathrm{C}-8$ and C-9 (Fig. 2). Just as the natural occurring analogs longamides A and $\mathrm{C}$ and mukanadin $\mathrm{C},{ }^{13,14}$ compound 2 was also obtained initially as enantisomers showing no optical activity and was chiral separated to obtain stable $(+)-2\left([\alpha]_{\mathrm{D}}^{25} 32.5, \mathrm{MeOH}\right)$ and $(-)-2\left([\alpha]_{\mathrm{D}}^{25}-28.5, \mathrm{MeOH}\right)$. A conformational search using Spartan software led to the conformers with respective quasiaxial OH-9 and quasiequatorial OH-9 conformations for both $9 S$ and $9 R$ configurations. Nevertheless, the small $J_{\mathrm{H}-9 / \mathrm{Ha}-8}$ value of $3.32 / 3.48 \mathrm{~Hz}$ except for the $5.12 \mathrm{~Hz}$ for $J_{\mathrm{H}-9 / \mathrm{OH}-9}$ of compound 2 indicated that $\mathrm{OH}-9$ should be quasiequatorial-originated. And TDDFT/ECD calculations indicated that the calculated ECD spectra of the lower energy conformers 2a1 and 2a2 with quasiaxial OH-9 matched well with those of (+)- and (-)-2 showing mirror-like CEs at 225 and $266 \mathrm{~nm}$ (Fig. 5, ESI †). Thus, the absolute configurations of $9 R$ and $9 S$ for respective $(+)-2$ and (-)-2, identical to the synthetic analogue $(S)$-(-)-longamide B $\left([\alpha]_{\mathrm{D}}^{25}-5.51, \mathrm{MeOH}\right),{ }^{15}$ were finally determined.

Nemoechine C (3), a white amorphous solid without optical activity, had a molecular formula of $\mathrm{C}_{10} \mathrm{H}_{14} \mathrm{~N}_{2} \mathrm{O}_{4}$, based on its HRESIMS and ${ }^{13} \mathrm{C}$ NMR data (Table 2). 1D NMR of compound 3 showed the typical pyrrole-2-carboxamido core and a butyric

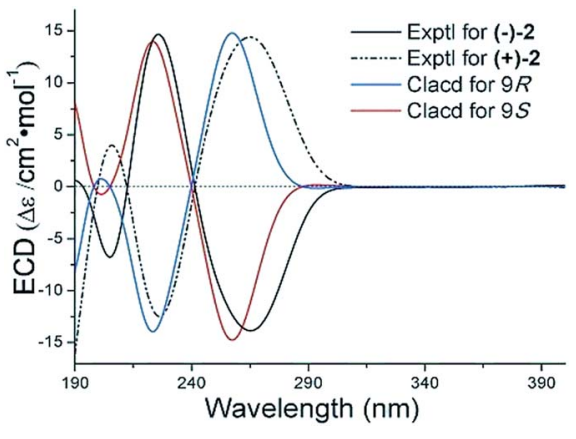

Fig. 5 Experimental CD spectrum of nemoechine B (2) overlaid with calculated spectra (redshifted by $10 \mathrm{~nm}$ ) for the candidate stereostructures.

side chain containing two methylenes $\left(\delta_{\mathrm{C}} 44.6,40.0\right)$, one oxygenated methine $\left(\delta_{\mathrm{C}} 66.7\right)$, and one carboxyl group $\left(\delta_{\mathrm{C}}\right.$ $171.7)$, as well as a methoxy $\left(\delta_{\mathrm{C}} 51.2\right)$, indicating that compound 3 was an analogue of acanthamide $\mathrm{A}$ isolated from sponge Acanthostylotella sp. ${ }^{16}$ In 2D NMR, two spin-coupling systems of $\mathrm{H}-1 / \mathrm{H}-2 / \mathrm{H}-3 / \mathrm{H}-4$ and $\mathrm{H}-7 / \mathrm{H}_{2}-8 / \mathrm{H}-9 / \mathrm{H}_{2}-10(\mathrm{OH}-9)$ evident from ${ }^{1} \mathrm{H}-{ }^{1} \mathrm{H}$ COSY spectrum of 3 indicated the partial structures of pyrrole core and side chain (Fig. 2), respectively. HMBC correlations from $\mathrm{MeO}$ and $\mathrm{H}_{2}-10$ to C-11, and from $\mathrm{H}-7$ and $\mathrm{H}_{2}-8$ to C-6 supported the attachment of the methyl-esterified side chain to carboxamide moiety as depicted. Compound 3 was further purified by chiral HPLC chromatography to obtain (+)-3 $\left([\alpha]_{\mathrm{D}}^{25} 10.1, \mathrm{MeOH}\right)$ and $(-)-3\left([\alpha]_{\mathrm{D}}^{25}-12.1, \mathrm{MeOH}\right)$. Absolute configurations of (+)-3 and (-)-3 were tentatively determined as $9 R$ and $9 S$ by comparing the OR values with those of the analogues $(+)-(R)$-debromodispacamide $\mathrm{D}\left([\alpha]_{\mathrm{D}}^{25} 41.7, \mathrm{MeOH}\right)$ and $(-)-(S)$-aspidostomide $\mathrm{A}\left([\alpha]_{\mathrm{D}}^{25}-26.5, \mathrm{MeOH}\right) \cdot{ }^{17}$

Nemoechine $\mathrm{D}(\mathbf{8})$ was obtained as a white amorphous solid with a molecular formula of $\mathrm{C}_{26} \mathrm{H}_{39} \mathrm{~N}_{5} \mathrm{O}$ as determined by HRESIMS and ${ }^{13} \mathrm{C}$ NMR (Table 3). The isolated aza-aromatic

Table $2{ }^{1} \mathrm{H}$ and ${ }^{13} \mathrm{C}$ NMR data of compounds 2 and 3 (recorded in DMSO- $d_{6}, \delta$ in ppm, $\mathrm{J}$ in $\mathrm{Hz}$ )

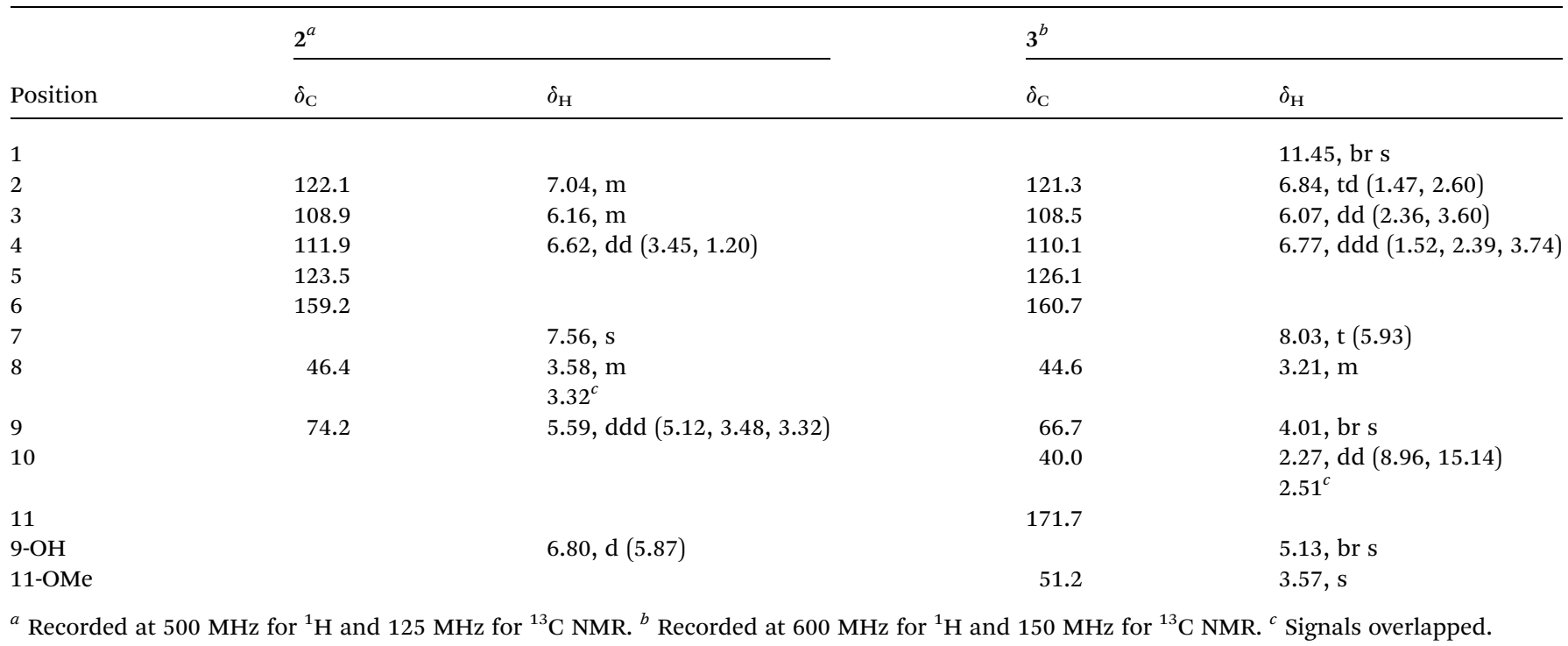


Table $3{ }^{1} \mathrm{H}$ and ${ }^{13} \mathrm{C}$ NMR data of compound 8 (recorded in DMSO- $d_{6}$, $\delta$ in ppm, $\mathrm{J}$ in $\mathrm{Hz})^{a}$

\begin{tabular}{|c|c|c|}
\hline Position & $\delta_{\mathrm{C}}$ & $\delta_{\mathrm{H}}$ \\
\hline 1 & 17.7 & $1.46, \mathrm{~m}$ \\
\hline 2 & 26.2 & $1.90, \mathrm{~m}, 1.47, \mathrm{~m}$ \\
\hline 3 & 120.2 & 5.09, br s \\
\hline 4 & 143.5 & \\
\hline 5 & 37.5 & \\
\hline 6 & 36.1 & $1.59, \mathrm{dt}(2.88,12.43), 1.05, \mathrm{dt}(3.60,12.39)$ \\
\hline 7 & 26.9 & $1.36, \mathrm{~m}, 1.34, \mathrm{~m}$ \\
\hline 8 & 35.5 & $1.38, \mathrm{~m}$ \\
\hline 9 & 38.1 & \\
\hline 10 & 45.7 & $1.22, \mathrm{~m}$ \\
\hline 11 & 36.1 & $1.37, \mathrm{~m}, 1.25, \mathrm{~m}$ \\
\hline 12 & 32.4 & $1.80, \operatorname{td}(4.38,13.20), 1.69, \mathrm{~m}$ \\
\hline 13 & 140.2 & \\
\hline 14 & 120.0 & $5.15, \mathrm{t}(6.26)$ \\
\hline 15 & 38.1 & $4.56, \mathrm{~d}(6.53)$ \\
\hline 16 & 16.5 & $1.73, \mathrm{~s}$ \\
\hline 17 & 15.8 & $0.71, \mathrm{~d}(6.41)$ \\
\hline 18 & 17.7 & $1.50, \mathrm{~s}$ \\
\hline 19 & 19.6 & $0.91, \mathrm{~s}$ \\
\hline 20 & 18.1 & $0.64, \mathrm{~s}$ \\
\hline $2^{\prime}$ & 150.8 & $8.03, \mathrm{~s}$ \\
\hline $4^{\prime}$ & 146.9 & \\
\hline $5^{\prime}$ & 104.3 & \\
\hline $6^{\prime}$ & 147.6 & \\
\hline $8^{\prime}$ & 152.3 & \\
\hline $6^{\prime}-\mathrm{NH}_{2}$ & & 6.43, br s \\
\hline $9^{\prime}-\mathrm{NMe}$ & 26.9 & $3.24, \mathrm{~s}$ \\
\hline
\end{tabular}

proton signal $\left(\delta_{\mathrm{H}} 8.03, \mathrm{~s}\right)$ and five skeletal methyl signals $\left(\delta_{\mathrm{H}}\right.$ 1.73 , s; 1.50 , s; 0.91, s; 0.71, d, $J=6.41 \mathrm{~Hz} ; 0.64, \mathrm{~s})$ in ${ }^{1} \mathrm{H}$ NMR spectrum of $\mathbf{8}$ suggested it as a purine-labdane diterpenoid alkaloid. And $\mathbf{8}$ was further deduced to be constructed by the two identical partial structures of respective labdane moiety in ageloxime $\mathrm{B}$ and purine moiety in $8^{\prime}$-oxo-agelasine $\mathrm{D}^{8}{ }^{8}$ The speculation was supported by analysis of 2D NMR of COSY, HMQC and HMBC spectra. Especially the HMBC correlations from $\mathrm{NMe}-9^{\prime}$ to $\mathrm{C}-4^{\prime}$ and $\mathrm{C}-8^{\prime}$, and from $\mathrm{H}_{2}-15$ to $\mathrm{C}-13, \mathrm{C}-14, \mathrm{C}-8^{\prime}$ and $\mathrm{C}-5^{\prime}$ indicated that the diterpene moiety was attached to $\mathrm{C}$ $7^{\prime}$ of the $9^{\prime}$-methyl adenine (Fig. 1). In the NOESY spectrum (Fig. 2), NOE correlations of $\mathrm{H}_{3}-20$ with $\mathrm{H}_{3}-19$ and $\mathrm{H}_{3}-17, \mathrm{H}-8$ with $\mathrm{H}_{\mathrm{b}}-11\left(\delta_{\mathrm{H}} 1.25\right), \mathrm{H}-10$ with $\mathrm{H}_{\mathrm{a}}-11\left(\delta_{\mathrm{H}} 1.37\right), \mathrm{H}_{3}-16$ with $\mathrm{H}_{2}$ 15 , and $\mathrm{H}_{2}-12$ with $\mathrm{H}-14$, together with the similar ${ }^{13} \mathrm{C}$ chemical shifts of the labdane moiety, ${ }^{8}$ suggested that compound 8 had the same configuration as ageloxime $\mathrm{B}$.

The molecular formula of nemoechioxide A (10) was determined as $\mathrm{C}_{18} \mathrm{H}_{32} \mathrm{O}_{4}$ by its HRESIMS and ${ }^{13} \mathrm{C}$ NMR data (Table 4). Four splitted aliphatic methyl groups including three triplets $\left(\delta_{\mathrm{H}} 0.89, \mathrm{t}, J=7.46 \mathrm{~Hz} ; 0.87, \mathrm{t}, J=5.95 \mathrm{~Hz} ; 0.79, \mathrm{t}, J=7.45 \mathrm{~Hz}\right)$ and one doublet $\left(\delta_{\mathrm{H}} 0.88, \mathrm{t}, J=6.47 \mathrm{~Hz}\right)$ in ${ }^{1} \mathrm{H}$ NMR spectrum of 10 were typical for polyketides. ${ }^{9 b}$ And compound 10 was further suggested as an lactone-opening derivative of plakortoxide $\mathrm{A},{ }^{\boldsymbol{9} \boldsymbol{b}}$ based on the evidence that $\mathbf{1 0}$ had relatively upshifted oxygenbearing quaternary carbon $\left(\delta_{\mathrm{C}} 73.5\right)$ and carboxyl carbonyl $\left(\delta_{\mathrm{C}}\right.$ 166.2) and one extra methoxyl group $\left(\delta_{\mathrm{C}} 51.4 ; \delta_{\mathrm{H}} 3.66\right)$. The COSY correlations of $\mathrm{H}-7 / \mathrm{H}-8 / \mathrm{H}-9\left(\mathrm{H}_{3}-17\right), \mathrm{H}_{2}-11 / \mathrm{H}_{3}-12$,
Table $4{ }^{1} \mathrm{H}$ and ${ }^{13} \mathrm{C}$ NMR data of compound 10 (recorded in DMSO$d_{6}, \delta$ in ppm, $J$ in $\mathrm{Hz}^{a}$

\begin{tabular}{lrl}
\hline Position & \multicolumn{1}{c}{$\delta_{\mathrm{C}}$} & \multicolumn{1}{l}{$\delta_{\mathrm{H}}$} \\
\hline 1 & 166.2 & \\
2 & 119.0 & $5.99, \mathrm{~d}(15.72)$ \\
3 & 152.8 & $6.93, \mathrm{~d}(15.72)$ \\
4 & 73.5 & \\
5 & 68.4 & $2.75, \mathrm{~s}$ \\
6 & 63.9 & $1.82, \mathrm{dd}(4.90,13.81)$ \\
7 & 42.3 & $0.79^{b}$ \\
& & $1.49, \mathrm{~m}$ \\
8 & 29.2 & $1.25, \mathrm{~m}$ \\
9 & 36.9 & $1.09, \mathrm{~m}$ \\
& & $1.25, \mathrm{~m}$ \\
10 & 28.7 & $1.25, \mathrm{~m}$ \\
11 & 22.4 & $0.87, \mathrm{t}(5.95)$ \\
12 & 14.0 & $1.61, \mathrm{~m}$ \\
13 & 31.5 & $1.66, \mathrm{~m}$ \\
& & $0.79, \mathrm{t}(7.45)$ \\
14 & 7.4 & $1.61, \mathrm{~m}$ \\
15 & 21.0 & $1.86, \mathrm{~m}$ \\
16 & & $0.89, \mathrm{t}(7.46)$ \\
17 & 9.3 & $0.88, \mathrm{~d}(6.47)$ \\
$1-O M e$ & 19.6 & $3.66, \mathrm{~s}$ \\
$4-O H$ & 51.4 & $5.00, \mathrm{~s}$ \\
${ }^{a}$ Recorded at $600 \mathrm{MHz}$ & & \\
overlapped. & & \\
& & \\
& &
\end{tabular}

$\mathrm{H}_{2}-15 / \mathrm{H}_{3}-16, \mathrm{H}_{2}-13 / \mathrm{H}_{3}-14$, and $\mathrm{H}-2 / \mathrm{H}-3$ (Fig. 1), together with $\mathrm{HMBC}$ correlations from $\mathrm{OMe}$ to $\mathrm{C}-1$, from $\mathrm{H}-2$ and $\mathrm{H}-3$ to $\mathrm{C}-1$ and $\mathrm{C}-4$, from $\mathrm{OH}$ and $\mathrm{H}_{3}-14$ to $\mathrm{C}-4$, from $\mathrm{H}-5$ to $\mathrm{C}-3, \mathrm{C}-4, \mathrm{C}-6$ and $\mathrm{C}-7$, from $\mathrm{H}_{3}-16$ to C-6, from $\mathrm{H}_{3}-17$ to $\mathrm{C}-7$ and $\mathrm{C}-9$, and from $\mathrm{H}_{3}-12$ to $\mathrm{C}-10$ completed the assignment of the structure. The large coupling constant of $J_{\mathrm{H}-2 / \mathrm{H}-3}=15.72 \mathrm{~Hz}$ suggested the $\mathrm{E}$ geometry of double bond $\mathrm{CH}-2=\mathrm{CH}-3$. In NOE difference spectrum, irritation of $\mathrm{H}-5\left(\delta_{\mathrm{H}} 2.75,1 \mathrm{H}, \mathrm{s}\right)$ generated enhancements of $\mathrm{H}_{2}-7\left(\delta_{\mathrm{H}} 1.82,1 \mathrm{H}, \mathrm{t}, \mathrm{dd}=13.81,4.90 \mathrm{~Hz} ; 0.79,1 \mathrm{H}\right.$, overlapped) and $\mathrm{H}-8\left(\delta_{\mathrm{H}} 1.49,1 \mathrm{H}, \mathrm{m}\right)$, indicating that $\mathrm{H}-5$ and ethyl moiety of $-\mathrm{CH}_{2}-15-\mathrm{CH}_{3}-16$ were located on opposite side of the epoxide ring. Nevertheless, the configurations of C-4 and C-8 remained to be determined due to the sample limit.

Additionally, seven known compounds were isolated from Agelas aff. nemoechinata, including (4) glycine, $\mathrm{N}$-(1H-pyrrol-2ylcarbonyl)-, methyl ester (CAS no. 62 409-33-0), ${ }^{18}$ (5) $1 H^{-}$ pyrrole-2-carboxamide, $N$-(3-hydroxypropyl)- (CAS no. 186 956$74-1),{ }^{19}$ (6) $1 H$-pyrrole-2-carboxamide, $N$-(2-aminoethyl)- (CAS no. 1183 721-98-3), ${ }^{20}$ (7) $1 \mathrm{H}$-pyrrole-2-carboxamide (CAS no. 4551-72-8), ${ }^{21}$ (9) 8'-oxo-agelasine D 8H-purin-8-one, 6-amino-7$[(2 E)-5-[(1 R, 4 \mathrm{a} R, 8 \mathrm{a} R)$-decahydro-5,5,8a-trimethyl 2-methylene1-naphthalenyl]-3-methyl-2-penten-1-yl]-7,9-dihydro-9-methyl(CAS no. 1360 451-92-8), ${ }^{8}$ (11) acetic acid, 2-[(5R)-3,5-diethyl-5[(2S)-2-ethylhexyl]-2(5H)-furanylidene]-, methyl ester, (2Z)-(CAS no. 206 443-26-7), ${ }^{22}$ (12) acetic acid, 2-[(5R)-3,5-diethyl-5-[(2S)-2methylhexyl]-2(5H)-furanylidene]-, methyl ester, (2Z)-(CAS no. 206 443-25-6), ${ }^{22}$ (13) acetic acid, 2-[(5R)-3-ethyl-5-[(2S)-2-ethylhexyl]-5-methyl-2(5H)-furanylidene]-, methyl ester, (2Z)-(CAS no. 887 267-98-3), ${ }^{23}$ (14) acetic acid, 2-[(5R)-3-ethyl-5-[(2R,3E)-2ethyl-3-hexen-1-yl]-5-methyl-2(5H)-furanylidene]-, methyl ester, 
(2Z)-(CAS no. 767 314-30-7). ${ }^{22}$ Their structures were determined by comparison of their spectroscopic data with those in the literature.

The cytotoxicities of compounds 1-14 were evaluated against four tumor cell lines, HeLa (cervical carcinoma), HL-60 (promyelocytic leukemia), K562 (erythroleukemia) and P388 (leukaemia), using the MTT method with adriamycin as the positive control. ${ }^{24}$ Diterpene alkaloids $\mathbf{8}$ and $\mathbf{9}$ showed cytotoxity against HL-60 cell lines with $\mathrm{IC}_{50}$ values of respective 9.9 and 0.9 $\mu \mathrm{M}$, respectively, and compound 9 was also cytotoxic against HeLa cell lines with $\mathrm{IC}_{50}$ value of $8.9 \mu \mathrm{M}$. And it was the first time to reveal the cytotoxicity feature of $8^{\prime}$-oxo-agelasine D (9) since the report of its lack of antimicrobial and antileishmanial activities. ${ }^{8}$ All of the compounds tested were inactive against the P388 and $\mathrm{K} 562$ cell lines $\left(\mathrm{IC}_{50}\right.$ value $\left.>10 \mu \mathrm{M}\right)$.

\section{Conclusions}

In conclusion, three kinds of metabolites including five pyrrole alkaloids (1-7), two pyrimidine diterpenes (8 and 9), and five polyketides (10-14) were obtained from a Xisha sponge Agelas aff. nemoechinata. The new compounds (1-3, 8, and 10), especially an unusual cyclopentene-fused imidazole ring system in $\mathbf{1}$ enriched chemo-diversity of Agelas genus. And the cyctotoxity feature of new pyrimidine diterpene (8) and the known analogue (9) was unveiled for a pharmaceutical potential. Most interestingly, almost all pyrrole alkaloids from Agelas sponge were brominated, while in present study the compounds (1-7) of the same family from the affinis species in Xisha islands were all non-brominated. That could imply a potential habitatspecificity of the Agelas genus in Xisha islands.

\section{Experimental section}

\section{General experimental procedures}

Optical rotations were measured on a Jasco P-1020 digital polarimeter. UV spectra were measured on a Beckman DU640 spectrophotometer. CD spectra were obtained on a Jasco J-810 spectropolarimeter. IR spectra were recorded on a Nicolet NEXUS 470 spectrophotometer using $\mathrm{KBr}$ discs. 1D and 2D NMR spectra were recorded on a JEOL JNMECP 600 and Bruker AVANCE III 500 spectrometers using residual solvent signals (for DMSO- $d_{6}: \delta_{\mathrm{H}} 2.50$ and $\delta_{\mathrm{C}} 39.52 \mathrm{ppm}$ ) as reference standards. HRESIMS was performed on a Micromass Q-TOF Ultima Global GAA076 LC-MS spectrometer. Semi-preparative HPLC utilized an ODS column [YMC-Pack ODS-A, $10 \times 250 \mathrm{~mm}, 5 \mu \mathrm{m}, 1.5 \mathrm{~mL}$ $\min ^{-1}$ ]. Chiral HPLC utilized chiral analytical columns [Daicel Chiralpack IC: $5 \mu \mathrm{m}, 4.6 \mathrm{~mm} \times 250 \mathrm{~mm}$ ]. Silica gel (200-300 mesh, Qingdao, China) was used for column chromatography, and precoated silica gel plates (GF254, Qingdao, China) were used for TLC. The cell lines for in vitro cytotoxicity studies were procured from Capital Medical University, Beijing, China.

\section{Animal material}

The sponge Agelas aff. nemoechinata was collected from Xisha islands (Paracel islands) in the South China Sea, in June 2009, at a depth of about $20 \mathrm{~m}$. The sponge was identified by one of the authors (N. J. D. V.). A voucher specimen (no. XS 2009-26) was deposited in the school of Medicine and Pharmasy, Ocean University of China, People's Republic of China.

\section{Extraction and isolation}

The frozen specimen ( $5.0 \mathrm{~kg}$, wet weight; $2.2 \mathrm{~kg}$, dry weight) was mined and extracted with $\mathrm{MeOH}$ three times (each time, 5 days) at room temperature. The combined solutions were concentrated in vacuum, and the concentrated extract was finally desalted by redissolving with $\mathrm{MeOH}$ three times to yield a residue (310.5 g). The crude extract was subjected to silica gel vacuum liquid chromatography (VLC), eluting with a gradient of petroleum/ acetone (from $10: 0$ to $1: 1, \mathrm{v} / \mathrm{v}$ ) to obtain seven fractions (F1F7). Fraction F2 (petroleum/acetone $10: 1,8.7 \mathrm{~g}, 0.4 \%$ of dry material weight) was chromatographed on a silica gel column using petroleum ether-acetone $(20: 1, \mathrm{v} / \mathrm{v})$ as eluent to give three subfractions (SF2-1-SF2-3). Subfraction SF2-2 (1.66 g, 0.07\% of dry material weight) was further separated on an ODS reversed-phase silica column using $\mathrm{MeOH} / \mathrm{H}_{2} \mathrm{O}(1: 1,3: 2,4: 1$ and $10: 0, \mathrm{v} / \mathrm{v})$ to give five fractions (SF2-2-1-SF2-2-5). Subfraction SF2-2-1 (0.26 g, $0.01 \%$ of dry material weight) was purified by HPLC (ODS; 5 um, $\left.250 \times 10 \mathrm{~mm} ; \mathrm{MeOH}-\mathrm{H}_{2} \mathrm{O}, 78: 22, \mathrm{v} / \mathrm{v} ; 1.5 \mathrm{~mL} \mathrm{~min}^{-1}\right)$ to afford compounds 10 (2.1 mg), 11 (4.0 mg), 12 (4.2 mg), 13 (3.9 mg), 14 (3.5 mg). Similarly, fractions F5 $\left(\mathrm{CH}_{3} \mathrm{Cl} / \mathrm{MeOH} 20: 1,8.0 \mathrm{~g}, 0.36 \%\right.$ of dry material weight) was subjected to CC on silica gel repeatedly and further purified by HPLC to give compounds $3(2.5 \mathrm{mg}), 4$ (6.0 mg), 5 (1.5 mg), 7 (30 mg), 8 (8.0 mg), and 9 (8.6 mg). And compounds 1 (2.2 mg), 2 (7.2 mg), and 6 (2.5 mg) were obtained from $\mathrm{S} 6\left(\mathrm{CH}_{3} \mathrm{Cl} / \mathrm{MeOH} 1\right.$ : 1, $5.2 \mathrm{~g}, 0.24 \%$ of dry material weight). Chiral separations of partial 1 [Daicel Chiralpack IC, $5 \mu \mathrm{m}, 4.6$ $\mathrm{mm} \times 250 \mathrm{~mm}$; hexane/isopropyl alcohol $\left.70: 30,1.5 \mathrm{~mL} \mathrm{~min}^{-1}\right]$, 2 [Daicel Chiralpack IC, $5 \mu \mathrm{m}, 4.6 \mathrm{~mm} \times 250 \mathrm{~mm}$; hexane/ isopropyl alcohol $75: 25,1.5 \mathrm{~mL} \mathrm{~min}^{-1}$ ], and 3 [Daicel Chiralpack IC, $5 \mu \mathrm{m}, 4.6 \mathrm{~mm} \times 250 \mathrm{~mm}$; hexane/isopropyl alcohol $\left.70: 30,1.5 \mathrm{~mL} \mathrm{~min}^{-1}\right]$ were performed on Agilent analytical HPLC system to afford optically pure $(+)-\mathbf{1}(0.9 \mathrm{mg}),(-)-\mathbf{1}(1.1 \mathrm{mg}),(+)-2$ (1.0 mg), (-)-2 (1.1 mg), (+)-3 (1.0 mg), and (-)-3 (1.3 mg).

\section{Computational section}

The quantum chemical calculations were performed by using the density functional theory (DFT) as carried out in the Gaussian 09. ${ }^{25}$ The initial structures of compounds 1 and 2 were built with Spartan 10 software and all trial structures were firstly minimized based on molecular mechanics calculations. Conformational search was performed by Spartan 10 software using MMFF force filed, and conformers occurring within a 10 kcal $\mathrm{mol}^{-1}$ energy window from the global minimum were chosen for geometry optimization in the gas phase with the DFT method at the B3LYP/6-31G(d,p) levels. The stable conformations of 1 and 2 were calculated for ECD spectra using TD-DFT method with the basis set RB3LYP/DGDZVP. ${ }^{26}$ Solvent effects of methanol solution were evaluated at the same DFT level by using the SCRF/PCM method. Electronic transitions were expanded as Gaussian curves with a FQHM (full width at half maximum) for each peak of 0.6 and $0.32 \mathrm{eV}$ for respective 1 and 
2. The ECD spectra were combined after Boltzmann weighting according to their population contribution (Fig. S1-S4 in ESI $\dagger$ ).

( \pm )-Nemoechine A (1). Colorless amorphous solid; UV $(\mathrm{MeOH})(\log \varepsilon) \lambda_{\max } 267$ (2.70), 217 (2.92); IR (KBr) $\nu_{\max }$ 3266, 2922, 2360, 1684, 1649, 1559, 1521, 1380, 1068, 894, 628, $604 \mathrm{~cm}^{-1} ;{ }^{1} \mathrm{H}$ and ${ }^{13} \mathrm{C}$ NMR data, see Table 1 ; ESIMS $\mathrm{m} / z 303.2$ $[\mathrm{M}+\mathrm{Na}]^{+}$; HRESIMS $m / z$ 303.1061 $[\mathrm{M}+\mathrm{Na}]^{+}$(calcd for $\left.\mathrm{C}_{12} \mathrm{H}_{16} \mathrm{O}_{4} \mathrm{~N}_{4} \mathrm{Na}, 303.1064\right)$. (+)-1 $[=N-((3 \mathrm{a} R, 4 R, 5 S, 6 \mathrm{a} R)-5$-hydroxy$6 a$-methoxy-2-oxooctahydrocyclopenta $[d]$ imidazol-4-yl)- $1 H$-pyrrole2-carboxamide]: $[\alpha]_{\mathrm{D}}^{25} 30.3(c 0.08, \mathrm{MeOH}) ; \mathrm{CD}(c 0.0008 \mathrm{M}, \mathrm{MeOH})$ $\lambda_{\max }(\Delta \varepsilon) 197.5$ (5.4), $264.5(8.0) \mathrm{nm} ;(-)-1$ [ $=N-((3 \mathrm{a} S, 4 S, 5 R, 6 \mathrm{a} S)-5-$ hydroxy-6a-methoxy-2-oxooctahydrocyclopenta[d]imidazol-4-yl)-1 $H$ pyrrole-2-carboxamide]: $[\alpha]_{\mathrm{D}}^{25}-32.4(c \quad 0.0867, \mathrm{MeOH}) ; \mathrm{CD}(c$ $0.0008 \mathrm{M}, \mathrm{MeOH}) \lambda_{\max }(\Delta \varepsilon) 264.5(-7.8) \mathrm{nm}$.

( \pm )-Nemoechine B (2). Colorless oil; UV (MeOH) $(\log \varepsilon) \lambda_{\max }$ 269 (2.10), 230 (2.45); IR (KBr) $\nu_{\max } 3278,2927,2365,1641,1556$, 1471, 1338, 1099, 1061, 848, 749, $695 \mathrm{~cm}^{-1} ;{ }^{1} \mathrm{H}$ and ${ }^{13} \mathrm{C}$ NMR data, see Table 1; ESIMS $m / z$ 153.07 $[\mathrm{M}+\mathrm{H}]^{+}$; HRESIMS $m / z$ 153.0659 $[\mathrm{M}+\mathrm{H}]^{+}$(calcd for $\left.\mathrm{C}_{7} \mathrm{H}_{9} \mathrm{O}_{2} \mathrm{~N}_{2}, 153.0659\right) .(+)-2[=(R)-4-$ hydroxy-3,4-dihydropyrrolo[1,2- $a]$ pyrazin-1(2H)-one]: $[\alpha]_{\mathrm{D}}^{25} 32.5$ (c 0.193, MeOH); CD (c $0.0008 \mathrm{M}, \mathrm{MeOH}) \lambda_{\max }(\Delta \varepsilon) 206$ (4.0), 226.5 (-12.5), 265 (14.4) nm; (-)-2 [=(S)-4-hydroxy-3,4-dihydropyrrolo[1,2- $a]$ pyrazin-1(2H)-one $]: \quad[\alpha]_{\mathrm{D}}^{25}-28.5 \quad(c \quad 0.167$, $\mathrm{MeOH}) ; \mathrm{CD}(c 0.0008 \mathrm{M}, \mathrm{MeOH}) \lambda_{\max }(\Delta \varepsilon) 205(-6.8), 225.5$ (14.7), $265(-13.9) \mathrm{nm}$.

$( \pm)$-Nemoechine C (3). White, amorphous solid; UV (MeOH) $(\log \varepsilon) \lambda_{\max } 265$ (2.83), 206 (2.78); IR (KBr) $\nu_{\max } 3257,2931,2361$, 1731, 1633, 1564, 1526, 1439, 1328, 1200, 1027, $739 \mathrm{~cm}^{-1} ;{ }^{1} \mathrm{H}$ and ${ }^{13} \mathrm{C}$ NMR data, see Table 1; ESIMS $m / z$ 249.0 $[\mathrm{M}+\mathrm{Na}]^{+}$; HRESIMS $m / z 249.0851[\mathrm{M}+\mathrm{Na}]^{+}$(calcd for $\mathrm{C}_{10} \mathrm{H}_{14} \mathrm{O}_{4} \mathrm{~N}_{2} \mathrm{Na}$, 249.0846). (+)-3 [=methyl (R)-3-hydroxy-4-(1H-pyrrole-2carboxamido)butanoate]: $[\alpha]_{\mathrm{D}}^{25} 10.1$ (c $\left.0.0467, \mathrm{MeOH}\right) ; \mathrm{CD}(c$ $0.0008 \mathrm{M}, \mathrm{MeOH}) \lambda_{\max }(\Delta \varepsilon) 199.1(-7.8), 232.8$ (3.4), 263.3 $(-9.3), 302.0$ (4.3), 347.3 (3.6) nm; (-)-3 [=methyl ( $S$ )-3-hydroxy4-(1H-pyrrole-2-carboxamido)butanoate]: $[\alpha]_{\mathrm{D}}^{25}-12.1$ (c 0.0533, $\mathrm{MeOH}) ; \mathrm{CD}(c 0.0008 \mathrm{M}, \mathrm{MeOH}) \lambda_{\max }(\Delta \varepsilon) 199.1(-7.8), 232.8$ (3.4), 263.3 (-9.3), 302.0 (4.3), 347.3 (3.6) nm.

Nemoechine D (8). [=6-Amino-9-methyl-7- $((E)-3-$ methyl-5$((1 S, 2 R, 4 \mathrm{a} R, 8 \mathrm{a} R)-1,2,4 a, 5$-tetramethyl-1,2,3,4,4a,7,8,8a-octahydronaphthalen-1-yl)pent-2-en-1-yl)-7,9-dihydro-8H-purin-8-one]: white, amorphous solid; $[\alpha]_{\mathrm{D}}^{25}-20.1$ ( $c$ 0.533, MeOH); UV $(\mathrm{MeOH})(\log \varepsilon) \lambda_{\max } 273$ (3.24), 218 (2.51); IR (KBr) $\nu_{\max } 3315$, $3188,2923,1709,1635,1510,1441,1368,1164,858 \mathrm{~cm}^{-1} ;{ }^{1} \mathrm{H}$ and ${ }^{13} \mathrm{C}$ NMR data, see Table 2; ESIMS $m / z 438.3[\mathrm{M}+\mathrm{H}]^{+}$; HRESIMS $m / z 438.3239[\mathrm{M}+\mathrm{H}]^{+}$(calcd for $\mathrm{C}_{26} \mathrm{H}_{40} \mathrm{ON}_{5}, 438.3227$ ).

Nemoechinoxide A (10). [=Methyl $(E)-4-((2 S, 3 S)-3-e t h y l-3-(2-$ methylhexyl)oxiran-2-yl)-4-hydroxyhex-2-enoate]: colorless oil; $[\alpha]_{\mathrm{D}}^{25} 62.2$ ( $c$ 0.133, MeOH); UV (MeOH) (log $\left.\varepsilon\right) \lambda_{\max } 210$ (2.48); IR (KBr) $\nu_{\max } 3508,2958,2929,2357,1726,1461,1308,1271,1197$, 1169, 1018, 928, 840, 568, $482 \mathrm{~cm}^{-1} ;{ }^{1} \mathrm{H}$ and ${ }^{13} \mathrm{C}$ NMR data, see Table 3; ESIMS $m / z$ 235.0 [M + Na] ${ }^{+}$; HRESIMS $m / z$ 335.2197 [M + $\mathrm{Na}]^{+}$(calcd for $\mathrm{C}_{18} \mathrm{H}_{32} \mathrm{O}_{4} \mathrm{Na}, 335.2193$ ).

\section{Cytotoxicity assay}

The cytotoxicity of compounds 1-14 against HeLa, HL-60, K562 and P388 cell lines were determined by MTT method with
Adriamycin as a positive control. ${ }^{23}$ The $\mathrm{IC}_{50}$ value of each compound was calculated by Reed and Muench's method.

\section{Acknowledgements}

This work was supported by National Natural Science Foundation of China (No. 21572210, 41376142 and 41522605), NSFCShandong Joint Fund for Marine Science Research Centers (Grant No. U1406402), AoShan Talents Program Supported by Qingdao National Laboratory for Marine Science and Technology (No. 2015ASTP), and Science and Technology program of applied basic research projects of Qingdao Municipal (No. 14-24-32-jch). Special thanks are given to Professor J. Li (Ocean University of China, Qingdao, China) for the cytotoxicity tests.

\section{Notes and references}

1 WoRMS Editorial Board (2015). World Register of Marine Species (Flanders Marine Institute). Available from http:// www.marinespecies.org at VLIZ.

2 (a) J. W. Blunt, B. R. Copp, R. A. Keyzers, M. H. G. Munro and M. R. Prinsep, Nat. Prod. Rep., 2014, 31, 160-258; (b) Y. Zhu, L.-L. Hong, J.-H. Gan, S.-J. Piao and W.-H. Jiao, Zhongguo Haiyang Yaowu, 2013, 32, 97-110.

3 K. Ishida, M. Ishibashi, H. Shigemori, T. Sasaki and J. Kobayashi, Chem. Pharm. Bull., 1992, 40, 766-767.

4 C. Eder, P. Proksch, V. Wray, R. W. van Soest, E. Ferdinandus, L. A. Pattisina and S. Sudarsono, J. Nat. Prod., 1999, 62, 1295-1297.

5 J. Appenzeller, G. Mihci, M.-T. Martin, J.-F. Gallard, J.-L. Menou, N. Boury-Esnault, J. Hooper, S. Petek, S. Chevalley, A. Valentin, A. Zaparucha, A. Al-Mourabit and C. Debitus, J. Nat. Prod., 2008, 71, 1451-1454.

6 T. Hattori, K. Adachi and Y. Shizuri, J. Nat. Prod., 1997, 60, 411-413.

7 S. Forenza, L. Minale, R. Riccio and E. Fattorusso, Chem. Commun., 1971, 18, 1129-1130.

8 F. Yang, M. T. Hamann, Y. Zou, M.-Y. Zhang, X.-B. Gong, J.-R. Xiao, W.-S. Chen and H.-W. Lin, J. Nat. Prod., 2012, 75, 774-778.

9 (a) C. Liu, X. Tang, P. Li and G. Li, Org. Lett., 2012, 14, 19941997; (b) J. Zhang, X. Tang, J. Li, P. Li, N. J. de Voogd, X. Ni, X. Jin, X. Yao, P. Li and G. Li, J. Nat. Prod., 1999, 76, 600-606; (c) Q. Wang, X. Tang, X. Luo, N. J. de Voogd, P. Li and G. Li, Org. Lett., 2015, 17, 3458-3461.

10 (a) T. Li, B. Wang, N. J. de Voogd, X. L. Tang, Q. Wang, M. J. Chu, P.-L. Li and G. Q. Li, Chin. Chem. Lett., 2016, 27, 1048-1051; (b) W. J. Song, Study on Chemical Constituents and Bioactivities of the Sponge Agelas Aff. nemoechinata. Master's thesis, Ocean University of China, 2014; (c) W. J. Song, J. Yan, Z. Liang, P. L. Li, X. L. Tang and G. Q. Li, Chin. J. Mar. Drugs, 2014, 33, 59-62.

11 G. M. König and A. D. Wfught, Nat. Prod. Lett., 1994, 5, 141146.

12 A. Araki, M. Tsuda, T. Kubota, Y. Mikami, J. Fromont and J. Kobayashi, Org. Lett., 2007, 9, 2369-2371. 
13 (a) F. Cafieri, E. Fattorusso, A. Mangoni and O. TaglialatelaScafati, Tetrahedron Lett., 1995, 36, 7893-7896; (b) M. G. Banwell, A. M. Bray, A. C. Willis and D. J. Wong, New J. Chem., 1999, 23, 687-690.

14 T. Hertiani, R. Edrada-Ebel, S. Ortlepp, R. W. M. van Soest, N. J. de Voogd, V. Wray, U. Hentschel, S. Kozytska, W. E. G. Müller and P. Proksch, Bioorg. Med. Chem., 2010, 18, 1297-1311.

15 J. Patel, N. Pelloux-Léon, F. Minassian and Y. Valleé, J. Org. Chem., 2005, 70, 9081-9084.

16 S. S. Ebada, R. Edrada-Ebel, N. J. de Voogd, V. Wray and P. Proksch, Nat. Prod. Commun., 2009, 4, 47-52.

17 (a) C. Vergne, J. Appenzeller, C. Ratinaud, M.-T. Martin, C. Debitus, A. Zaparucha and A. Al-Mourabit, Org. Lett., 2008, 10, 493-496; (b) L. P. C. Patiño, C. Muniain, M. E. Knott, L. Puricelli and J. A. Palermo, J. Nat. Prod., 2014, 77, 1170-1178.

18 M. A. Jones, J. D. Morton, J. M. Coxon, S. B. McNabb, H. Y. Y. Lee, S. G. Aitken, J. M. Mehrtens, L. J. G. Robertson, A. T. Neffe, S. Miyamoto, R. Bickerstaffe, K. Gately, J. M. Wood and A. D. Abell, Bioorg. Med. Chem., 2008, 16, 6911-6923.

19 X. Zeng, S. Xu, Y. Li, W. Shi and Q. Deng, Youji Huaxue, 2004, 24, 802-805.

20 B. S. Takale, N. V. Desai, A. A. Siddiki, H. K. Chaudhari and V. N. Telvekar, Med. Chem. Res., 2014, 23, 1387-1396.

21 D. Wischang and J. Hartung, Tetrahedron, 2011, 67, 4048-4054.

22 R. S. Compagnone, I. C. Piña, H. R. Rangel, F. Dagger, A. I. Suárez, M. V. R. Reddy and D. J. Faulkner, Tetrahedron, 1998, 54, 3057-3068.
23 M. H. Kossuga, A. M. Nascimento, J. Q. Reimão, A. G. Tempone, N. N. Taniwaki, K. Veloso, A. G. Ferreira, B. C. Cavalcanti, C. Pessoa, M. O. Moraes, A. M. S. Mayer, E. Hajdu and R. G. S. Berlinck, J. Nat. Prod., 2008, 71, 334339.

24 M. C. Alley, D. A. Scudiero, A. Monks, M. L. Hursey, M. J. Czerwinski, D. L. Fine, B. J. Abbott, J. G. Mayo, R. H. Shoemaker and M. R. Boyd, Cancer Res., 1988, 48, 589-561.

25 M. J. Frisch, G. W. Trucks, H. B. Schlegel, G. E. Scuseria, M. A. Robb, J. R. Cheeseman, G. Scalmani, V. Barone, B. Mennucci, G. A. Petersson, H. Nakatsuji, M. Caricato, X. Li, H. P. Hratchian, A. F. Izmaylov, J. Bloino, G. Zheng, J. L. Sonnenberg, M. Hada, M. Ehara, K. Toyota, R. Fukuda, J. Hasegawa, M. Ishida, T. Nakajima, Y. Honda, O. Kitao, H. Nakai, T. Vreven, J. A. Montgomery Jr, J. E. Peralta, F. Ogliaro, M. Bearpark, J. J. Heyd, E. Brothers, K. N. Kudin, V. N. Staroverov, R. Kobayashi, J. Normand, K. Raghavachari, A. Rendell, J. C. Burant, S. S. Iyengar, J. Tomasi, M. Cossi, N. Rega, J. M. Millam, M. Klene, J. E. Knox, J. B. Cross, V. Bakken, C. Adamo, J. Jaramillo, R. Gomperts, R. E. Stratmann, O. Yazyev, A. J. Austin, R. Cammi, C. Pomelli, J. W. Ochterski, R. L. Martin, K. Morokuma, V. G. Zakrzewski, G. A. Voth, P. Salvador, J. J. Dannenberg, S. Dapprich, A. D. Daniels, Ö. Farkas, J. B. Foresman, J. V. Ortiz, J. Cioslowski and D. J. Fox, Gaussian 09, Revision A.1, Gaussian, Inc., Wallingford CT, 2009.

26 D. M. McCann and P. J. Stephens, J. Org. Chem., 2006, 71, 6074-6098. 